抄 録

順天堂医学 $40(1)$

P. $87 \sim 99$ (1994)

\section{平成 5 年度順天堂大学医学部共同生化研究室}

\title{
研究報告会* 抄録
}

Annual Reports from Division of Biochemistry, Central Laboratory for Medical Sciences, Juntedo University School of Medicine.

\section{[口演発表](演題 $1 \sim 3$ )}

1. 培養ラット肝細胞における毛細胆管収縮能と肝細胞 内アクチン量の日歯市変化について

一生理的胆汁うつ滞との関連一 小児科 丸山 剛志 林 泉彦 入戸野 博 田和 俊也 時田 章史

目的 : 哺乳類の新生児期における生理的胆汁うつ滞と毛 細胆管機能の関係を明らが沉する.

方法 : 日齢 $1 \sim 60$ の Wistar 系ラットの培養肝細胞にお ける毛細胆管収縮能，アクチンの細胞内分布および肝内 蛋白に対する相対量, 血清総胆汁酸值の日齢変化を検討 した。

結果 : 毛細胆管の収縮率は日齢とともに増加し, 日齢 25 で adult level に達した. 日齢 1 のラット肝細胞のアク チンは毛細胆管周囲への集積が息しく，さらに肝内蛋白 に対するアクチンの相対量も生後増加して日齢30で adult level 亿達した。 また血清総胆汁酸值は日齢25にピ一 ク值を示した後減少した。

考案 : 血清総胆汁酸值から見た胆汁酸排泄機構の完成時 期と毛細胆管収縮能の完成時期が二致したてとから，毛 細胆管機能の未熟性が生理的胆汁うつ滞の一因となって いると推測され，その原因として幼若肝細胞でのアクチ ン分布の差および肝細胞内アクチン量の関与が示唆され た。

* 平成 5 年 12 月 7 日於順天堂大学医学部 9 号館 2 番教室 [Jan. 7, 1994 原稿受領] (Feb. 24, 1994 掲載決定)
2. 巣状糸球体硬化症 (FGS) モデルにおける।型コラー ゲンの遺伝子発現の局在

腎藏内科 長田しをり 海老原 功 中村司 福井 光峰 富野康日己 小出輝

目的：巣状糸球体硬化症（FGS） モデルラットの腎に おける I 型コラーゲン $\left(\alpha_{1}(\mathrm{I})\right)$ mRNA の局在につい て検討した。

方法：ピューロマイシンアミノヌクレオシド (DAN ) による FGS モデルラットの腎において $\alpha_{1}$ (I) cR NA プローブを用いて in situ hybridization を行い, そ の後PAS 染色した.また, 連続切片を抗ラットマクロ ファージ抗体 (ED-1) や抗 I 型コラーゲン抗体で免疫 染色し， $\alpha_{1}(\mathrm{I})$ を産生する細胞について検討した。

結果： $\alpha_{1}(\mathrm{I}) \mathrm{mRNA}$ のシグナルは糸球体上皮細胞, ボーマン囊上皮細胞と思われる細胞, 癒着部位の細胞, および間質の細胞に認められた。糸球体硬化の進行とと もにシグナルは増加した. ED-1 陽性細胞と $\alpha_{1}$ (I) mR NA 陽性細胞とは一致しなかった. 抗 I 型コラーゲン抗 体強陽性領域には $\alpha_{1}$ (I) mRNA 陽性細胞は認められ なかった。

\section{3. 大腸癌患者における便中胆汁酸組成比測定の臨床的} 意義

$$
\begin{array}{rrrr}
\text { 第一外科 鎌野 俊紀 中村 啓 } \\
\text { 岩瀬 博之 村田 敦子 }
\end{array}
$$

目的 : 大腸癌患者の便中胆汁酸を測定し, その臨床的意 義について報告した。

方法 : 対象は本学第一外科で切除された大腸癌 36 症例を 用い, 術前・術後の便中胆汁酸 (二次胆汁酸である deoxycholic acid (DCA) と一次胆汁酸である cholic acid (CA) を同一症例で Enzyme Linked Immunosorbent Assay (ELISA) 法で測定し, 組成比（DCA 
／CA）をみた。あわせて健常者18例についても測定し た.

結果 : 大腸癌における術前の便中胆汁酸組成比 (DCA ＣA） は0.4〜7.2亿対し, 術後の組成比は0.03〜1.3, 健常者は0.02〜2.7であった。 大腸癌全症例において術 後值は術前值より低值を示し, 健常者とほぼ同じ值を示 した. 癌占居部位, Dukes 分類では差はみられなかっ た. 他疾患患者の術後值は術前值に比し全例低值を示さ ず，ばらつきがみられた．組成比の cut off 值を1.0〜2.0 とすると大腸癌の術前症例では約 $70 \%$ が拾いあげ可能と なり, 大腸癌の検診に有用であると考えられた。

\section{〔誌上発表】(演題 $1 \sim 38$ )}

1. 先天性水頭症に対する C-type ナトリウム利尿ペプ チド（CNP）の効果に関する実験的研究

脳神経外科 宮嶋 雅一 佐藤 潔 新井一荻野 郁子

目的 : 私達は南野らが豚の脳より単離した第三のナトリ ウム利尿ペプチドに着目し, 乙れを用いた先天性水頭症 治療の可能性を検討した。

対象・方法：1）CNP 亿対する培養アストロサイト細 胞内 c-GMP 産生能の検討 ; 生後 1 日齢の HTX ラッ トと Wister ラットの大脳皮質より, それぞれアストロ サイトを 2 次培養し, CNP 亿対する c-GMP の産生能 を比較検討した。 2) CNP の頭蓋内圧および髄液吸収 抵抗付対する効果; 生後 $2 \sim 3$ 週齢の水頭症発現 HTX ラットの脳室内に定位的に10 $\mu g / \mu l$ の CNP を投与 し, Marmarouの方法により頭蓋内圧をモニターしつ つ, 髄液吸収抵抗值の変化を算出した, 対照実験として 同一ラットの脳室内に $10 \mu l$ の生食を投与した。

結果：1) CNP 亿対するアストロサイトc-GMP の産 生能は CNP の濃度と平行して増大した。 また, HTX ラットと Wister ラットの c-GMP 産生能には差を認め なかった. 2) CNP 投与により頭蓋内圧の低下と髄液 吸収抵抗の減少を認めた。

考察 : CNP に対する receptor は広く脳内のアストロ サイトに認められ, c-GMP を介して水分電解質の調節 に関与するものと推察されるが, 頭蓋内圧と髄液吸収抵 抗值の下降の機序の解明には, なお, 追加実験が必要と 考えられた。
2. 栄養障害型表皮水疮症と VII 型コラーゲン遺伝子 多型との関連について

皮膚科 須賀 康 真鍋 求

高森 建二 小川 秀興

目的 : 栄養障害型表皮水疱症の病態生理を明らかにする ため, VII 型コラーゲン遺伝子異常の解析を施行した.

方法 : VII 型コラーゲン遺伝子と栄養障害型表皮水疮症 原因遺伝子の相関性をゲノム DNA を用いた PCR-SS CP, PCR-RFLP 解析を施行することにより検討した. 結果 : SSCP・RFLP 解析による多型性は, 優性・劣性 両病型の栄養障害型表皮水疱症家系で認められ，乙れら の多型性は優性型とは強い相関性が認められ, 劣性型と は相関性が認められなかった。

考察：優性栄養障害型表皮水疱症は VII 型コラーゲン 遺伝子異常により発症するが, 劣性型ではその他の遺伝 子異常により発症しているてとが示唆された. 今後, さ らに塩基配列を決定して多型性の生じる原因を検索して いきたい。

\section{3. 培養ケラチノサイトのエンドセリン-1 発現に対する 紫外線照射（UVB）の影響}

共同生化 佐藤 ちよ 皮膚科 坪井 良治

目的：エンドセリン-1（ET-1）は, 血管内皮細胞由来 の収縮因子として発見された生理活性ペプチドであるが, 最近ケラチノサイトに対しても増殖因子として作用する ことが明らかとなった. 今回, われわれは培養ケラチノ サイトを用いて，UVB 照射がET-1および ETBレセプ タ一発現に及ぼす影響を検討した。

方法 : 無血清培地にて培養した正常ヒトケラチノサイト にUVB を照射し, 培養上清中のET-1 を RIA で定量 し, mRNA 発現を northern blot, RT-PCR で検討 した.

結果 : 未照射ケラチノサイトは, $2.4 p g / \mathrm{day} / 10^{6} \mathrm{cel}-$ 1s の ET-1 産生した. $10 \mathrm{~mJ} / \mathrm{cm}^{2}$ までの UVB 照射 で, 産生量は照射量に比例して増加した. ET-1 mRNA, ETB レセプターmRNA の発現は，いずれもUVB 照 射により著明に増加した. 以上のてとから，エンドセリ ンが UVB 照射後に生じる皮膚の炎症に深く関与して いることが示唆された。 


\section{4. マウス髭器官培養系における epimorphin の効果}

皮膚科 阿波隆夫 植木 理恵 今井 龍介 小川 秀興

目的 : 最近, 平井らは上皮の形態形成を促す新規蛋白質 を見い出し，てれを epimorphin（EPM）として報告 しているが，毛包もまた上皮組織のひとつであり EPM が毛包に対して何らかの効果を示す可能性が考光られた ため, 以下の実験を行った。

方法 : 平井より供与されたりコンビナント EPM を当研 究室で開発されたマウス卸毛包組織の器官培養系を用い て72時間の毛伸長と ${ }^{3} \mathrm{H}$-チミジンの取り込み量を測定し た。

結果 : EPM $0.1 \mu \mathrm{g} / \mathrm{ml}$ 加ら $1 \mu \mathrm{g} / \mathrm{ml}$ 亿扔て若干 の髭の伸長促進と ${ }^{3} \mathrm{H}$-チミシシンの取り込み量の増加がみ られたが，有意な差は認められなかった。

考察 : EPM は, マウス髭の毛成長に対して若干の促進 効果があるように思われるが，今回用いた実験系ではそ の効果を十分に認めることが出来なかった，今後は実験 条件を再検討するとともに，より効果が強いとされる $\mathrm{E}$ PMの多量体を用いた実験を検討している.

\section{5.インスリン様細胞増殖因子（IGF-I）とその結合蛋 白（BP-1）の相互作用について \\ 皮膚科 石 重明. 坪井 良治} 目的: 従来, インスリン様細胞増殖因子 (insulin-like growth factor-I, IGF-I）に対して，その結合蛋白 (binding protein-1，BP-I）はIGF-I の受容体への結 合を妨げるため，IGF-I の作用を抑制すると考元られて いた. われわれは, in vitro の培養ケラチノサイトの増 殖実験および in vivo の正常家兔を用いた創傷治癒実 験で IGF-I と BP-1 の相互作用を検討した。

方法：1）正常ヒトケラチノサイトを培養し, 乙れ種々 の濃度の IGF-I と BP-1 を添加し, 細胞数の増加を測 定した．2）正常家鬼の耳に直径 $6 \mathrm{~mm}$ の円形全層皮膚 欠損を作製し, 7 日後の創傷治癒の程度を組織学的に検 討した。

結果 : BP-1 が IGF-I のケラチノサイトの増殖と創傷の 上皮化を促進し, 新生肉芽組織, 毛細血管数を増加させ ることを見いだした．BP-1 自身には増殖促進作用は認 められないものの, 創傷治癒実験では単独投与でも治癒 促進効果が認められた。
6. 可溶可ヒト Fe $\varepsilon$ R I $\alpha$ 鎖を用いた ELISA による アトピー性皮膚炎患者 $\operatorname{IgE}$ の測定

$\begin{array}{cccc}\text { 皮膚科 } & \text { 須藤 } & \text { - } & \text { 小川 秀興 } \\ \text { 免疫学 和田 } & \text { 成仁 } & \text { 羅 } & \text { 智靖 } \\ \text { 奥村 } & \text { 康 } & \end{array}$

目的: 今回われわれは soluble $\alpha$ (ヒト Fc $\varepsilon \mathrm{R} \mathrm{I} \alpha$ 鎖 の細胞外ドメインの $95 \%$ 含含む可溶化ヒト Fc $\varepsilon$ R I $\alpha$ 鎖細胞外ドメイン）を用いてアトピ一性皮膚炎患者 (AD) 亿おける Fc $\varepsilon$ R I 結合性の IgE 值を測定した.

方法: 対象はアトピ一性皮膚炎患者 66 名, 正常人 13 名と した. 血清 $\operatorname{IgE}$ 值は soluble $\alpha$-ELISA 法 (soluble $\alpha$ をプレコートして, 実際に Fc $\varepsilon$ R I 亿結合する IgE 值 を測定する）と，従来のサンドイッチ ELISA 法（全 IgE 值を測定する) にてアッセイした.

まとめ: アレルギ一患者では全 $\mathrm{IgE}$ 值に対する $\mathrm{F} c \varepsilon \mathrm{R}$ I 結合性 IgE 值の割合はかなり低下していた，以上よ り $\mathrm{IgE}$ 分子には $\mathrm{Fc} \varepsilon \mathrm{R} I$ に結合し得ない種類の分子が 存在するか, あるいは血清中には IgE の Fc $\varepsilon$ R I への 結合を阻害する因子が存在する可能性が示唆され，また てのような病態が AD においても存在していると思わ れた。

\section{7. 黒質・線条体培養法を用いた，ドパミン神経に対す る鉄および鉄-メラニン複合体の毒性の検討}

脳神経内科 望月 秀樹 水野 美邦 都神経研究所神経学部門 西 克典

目的 : 近年パーキンソン病の主要病変である黒質におい て, 鉄の含有量が増加していることが報告されている. 今回われわれは黒質・線条体培養細胞系を用いて，鉄お よび鉄-メラニン複合体のドパミン神経毒性について検 討した。

方法 : 黒質・線条体神経細胞培養法は, 妊娠ラット（胎 生14日）から胎児を取り出し中脳および線条体を取り出 し細切し, 血清培地で分散培養した. 種々の濃度の三価 鉄およびドパミンメラニンを添加し，抗チロシン水酸化 酵素抗体を用い免度組織化学法で形態学的倹討した。 さらに培養中における脂質化酸化反応物質を, チオバル ビツール（TBA）法により測定した.

結果 : 形態学的な検討では, 鉄単独群において, 用量依 存性にドパミンニューロン数の有意な減少を認めた。 鉄メラニン複合体は，鉄単独よりも細胞毒性は強く，それ らは鉄キレート剂で抑制された。鉄-メラニン複合体群 では脂質過酸化物の生成の増加を認めた。 
8. 慢性呼吸不全モデルラットにおける諸臓器 RNA 量 の経時的変化の検討

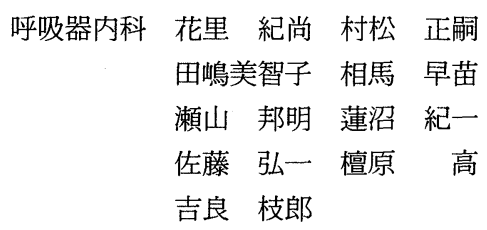

目的：慢性呼吸不全合併症としての各種臓器不全病態を 理解するため, 各藏器の代謝活動を評価する第一段階と して単位臓器重量当たりの RNA 量の経時的変化を検 討した。

方法 : 雄の SD ラットを低圧タンク内で高度 $5400 m$ （気 圧 $380 \mathrm{~mm} \mathrm{Hg} ）$ 亿相当する環境で飼育した。飼育後 0 日, 1 日，3 日，7日，14日，21日，28日の各時期に，4 匹以 上の SD ラットから心臓・肺・横隔膜・脳・腎藏・肝臓・ 脾臓・骨格筋を摘出し, total RNA を抽出した。

結果および考察 : hypobaric hypoxia の環境下で飼 育したラットの各蔵器 RNA 量 ( $\mu g \mathrm{RNA}$ /藏器重量 g) は経時的に 3 種類のパターンの推移を示した．1）一 旦減少してから増加する (心蔵・腎臓・横隔膜）2）経 時的にゆっくり減少する（脳・肺・脾臟）3）経時的に ゆっくり増加する (肝蔵・骨格筋). 今回の検討は total RNA であり, 蛋白質合成や遺伝子発現の活動度を直接 的に反映する mRNA ではないが; hypobaric hypoxia 亿対する反応は臟器によって異なるてとが明らかと なり, 興味深い.

\section{9. サルコイドーシス（サ症）におけるウイルスの関与} に関する検討

\begin{tabular}{|c|c|c|c|}
\hline 呼吸器内科 & 田村 & 尚亮 & 岩瀬 \\
\hline & 鈴木 & 孝次 & 山本 \\
\hline & 花里 & 紀尚 & 大西 \\
\hline & 吉良 & & \\
\hline
\end{tabular}

目的 : サ症の病因としてウイルスが関与する可能性は以 前より推測され，その分離・同定の試みが続けられてい るが, 本症に関連したウイルス同定の報告はされていな い. 最近, 急速にレトロウィルスに関しての知見が集積 されてきており，その知見の下にレトロウイルスが本症 の発症に関与する可能性についての検討を行った。

対象・方法：18例のサ症症例の BALF 細胞をU 937 細 胞と共に 3 力月以上長期混合培養を行い, 次の検討を行っ た. (1) 合胞体細胞の形成, (2) 逆転写酵素活性, (3) 電 顕, (4) 血清中抗体の有無, (5) ウイルス遺伝子の同定.
結果 : 検討 18 例中 8 例で長期培養が可能であった. 合胞 体細胞の形成が観察された 2 例の培養上清中には，逆転 写酵素活性が認められた。しかし，乙の培養細胞の電顕 的検索では現在までのとてろウイルス粒子は同定できて いない. また,レトロウイルス様構造を持つ cDNA ク ローンを得たが, 遺伝子解析により内在性プロウイルス 遺伝子と判明した。

\section{0. 遺伝子導入を用いた癌細胞に対する特異的細胞傷害 性 T 細胞の誘導}

呼吸器内科 瀬戸口靖弘 能戸 幸司
岩神真一郎 田島美智子
清水 一枝 吉良 枝郎

目的 : 特異的細胞傷害性 T 細胞の誘導力澌待される B7 ・ B70遺伝子を癌細胞への導入と, 最適なB7・B70遺伝子 発現をえるための発現ユニットの構築.

方法 : B7・B70遺伝子をサブクローニングにより取り出 す.アデノウイルスタイプ 5 major late promoter (MLP)・サイトメガロウイルス immediate promoter $と$ enhancer (CMVP) ・ 癌遺伝子 erbB promoter (ERBP) の各々のプロモーターとSV40 RNA matulation signal を含んだ各外来遺伝子発現ユニットを 構築し, B7・B70遺伝子を組み込み, 肺癌患者より得ら れた胸水中の癌細胞で, それぞれの遺伝子の発現の強さ を mRNA レベル・タンパクレベルで評価する。また， モノクロナール抗体・FACS を用いて B7・B70を発現 した癌細胞をソーティングして, 未梢血リンパ球と混合 培養して, 癌特異的細胞障害性 $\mathrm{T}$ リンパ球が誘導され るかを評価する。

結果 : 現在進行中の project であり, 結果は後日に発表 する.

\section{1。喫煙肺における Carcinoembryonic antigen （CEA）の mRNA 発現の検討 \\ 呼吸器内科 大和田明彦 高橋 英気 三上 理 岡 正彦 山本 隆子 清水 一枝 吉良 枝郎}

目的: CEA mRNA の発現を In Situ Hybridization 法により非契煙肺と喫煙肺で比較検討する。

方法: 手術または剖検で得られた非契煙肺 $(n=9)$ と 契煙肺 $(n=9)$ で, CEA 特異的 Riboprobe を用いて in situ hybridization を施行した. mRNA 発現半定 
量化のため銀粒子数を測定した.

結果 : 非喫煙肺に比べ喫煙肺で明らかな mRNA 発現 の増加がみられ, 細胞当たりの銀粒子数は非契煙肺で 3.7 \pm 2.0 (Mean \pm SD )，哭煙肺で12.9土7.9であった $(\mathrm{p}<0.005)$. またヒト肺由来の細胞株を in vitro で契 煙刺激するとCEA mRNA 発現増加がみられた。

考案 : 喫煙により気道肺胞被覆液中の CEA 増加は以前 より知られていたが，その産生部位は不明であった。今 回の検討で喫煙が肺局所での CEA mRNA 発現を克 進させ, 蛋白産生を増加させるものと推論させられる。

\section{2. 結核性胸膜炎症例における $\mathrm{T}$ 細胞受容体 $\beta$ 鎖可変 部領域レパートアーの解析}

$\begin{array}{rrrr}\text { 呼吸器内科 } & \text { 高橋 } & \text { 和久 } & \text { 能戸 幸司 } \\ & \text { 佐藤 } \\ & \text { 昇 } & \text { 清水 一枝 } \\ & \text { 早苗 } & \text { 吉良 枝郎 }\end{array}$

目的: 結核性胸膜炎（Tb）における胸水中 $\mathrm{T}$ リンパ球 増加の意義を明汃にする目的で, $\mathrm{Tb}$ の胸水中リンパ球 (PEL) と末梢血中リンパ球（PBL）における T 細胞 受容体 $(\mathrm{TCR}) \beta$ 鎖可変部領域 $(\mathrm{V} \beta)$ の解析を行っ た。

方法: $\mathrm{Tb} 6$ 症例と癌性胸膜炎 ( $\mathrm{Ca}$ ) 3 症例を対象とし, PEL・PBL からRNA を抽出し TCRV $\beta$ のsense primer (22種類) と定常領域の antisense primer （1 種類）を用いた RT-PCR 法で, 各V $\beta$ レパートアー 遺伝子の半定量を行った。

結果 : Tb の PEL・PBL ともに各 TCRV $\beta$ 亿 clonality は認められなかったが, PEL に比しPBL でV $\beta 3$ のRNA 量が有意に低下していた（ $\mathrm{Tb} \cdot \mathrm{Ca}$ における $\mathrm{P}$ $\mathrm{EL}$ の V $\beta 3 / \mathrm{PBL}$ の $\beta 3$ は各々 $746 \pm 604,1.04 \pm 0.2$ 平均 $\pm \mathrm{SE}, \mathrm{P}<0.01$ ), また, 治療後の $\mathrm{Tb}$ 一症例で, PBL のV $\beta 3$ RNA 量の回復が見られた.

考案: $\mathrm{Tb}$ 症例で全身から胸腔内へ $\mathrm{V} \beta 3$ 陽性 $\mathrm{T}$ 細胞が 誘導された可能性が示唆され, 結核性胸膜炎の病態への 関与が考えられた。

13.ヒト培養胃癌細胞株を用いた転移モデルの開発 消化器内科 岩崎 良三 渡辺 純夫 大高 恵一 大野 康彦 清水由美子 広瀬美代子 佐藤 信紘

目的 : 癌細胞の転移のメカニズムは複雑なため, in vivo での検討は困難であり, in vitro の培養系で系を単純
化し，検討することが大変有用な手段と考えられる．し かし，ヒ卜培養胃癌細胞株を用いた転移のメカニズムを 検討する簡便なモデルは存在しない，そてで，われわれ はヒ卜培養胃癌細胞株を用いて in vitro 系で簡便に癌 細胞の遊走能や増殖活性を定量的に解析するモデルを開 発することにした。

方法 : 七ト培養胃癌細胞株を培養具の中央に一定面積の 円形 sheet 状に inoculation し, その後の細胞の周囲 への遊走性を経時的に位相差顕微鏡や time-lapse VT $\mathrm{R}$ で記録し, 画像解析装置を用いて, その転移の方向性・ 速度などを定量的に解析する。

結果 : 円形 sheet 状の癌細胞は一様に同心円上に広が り，増殖していくことが経時的に確認された。

\section{4. 抗ミトコンドリア抗体陰性の原発性胆汁性肝硬変の 診断における抗 M2 抗体の意義 \\ 消化器内科 北見 啓之 村松 永子 清水 秀剛 安達 博保 駒田 敏之 石川 雅邦 三上 秀明 横井 幸男 佐藤 信紘}

目的：抗乏トコンドリア抗体（AMA）は原発性胆汁性 肝硬変 $(\mathrm{PBC})$ 患者血清中で高頻度に検出されるが, $\mathrm{P}$ $\mathrm{BC}$ 亿特異的な抗 $\mathrm{M} 2$ 抗体 (anti-M2) の陽性率との間 には解離が見られる. 今回われわれは AMA 抗体価と anti-M2 発現様式との関連性について検討した.

方法: 臨床的・組織学的に PBC と診断した 129 例につ き, Immunoblot 法により 4 種類の対応抗原を同定し, 間接蛍光抗体法による AMA の抗体価と anti-M2 の発 現様式について検討した。

結果：AMA は129例中114例（88\%）で陽性であったが, anti-M2 は全例で陽性を示した. AMA 陰性の15例中 9 例 $(60 \%)$ では auti-M2 の反応抗原蛋白数は 1 つであ るのに対し, AMA320倍以上の高抗体価を示す64例中 34例 (53\%) では4 種類の anti-M2 がすべて陽性を示 し, AMA 抗体価と anti-M2 の反応抗原蛋白数との間 には有意の相関がみられた，以上の結果から anti-M2 は AMA 陰性例でも PBC の診断に有用であり, AMA の抗体価は anti-M2 の抗原蛋白数と関連することが示 唆された。 
15. $\mathrm{C}$ 型慢性肝疾患のインターフェロン療法に対する Neopterin 産生能の臨床的意義

$\begin{array}{llrrr}\text { 消化器内科 } & \text { 山口 } & \text { 泰 } & \text { 宮崎 } & \text { 招久 } \\ & \text { 村松 } & \text { 永子 } & \text { 石川 } & \text { 雅邦 } \\ & \text { 竹内 } & \text { 真 } & \text { 駒田 } & \text { 敏之 } \\ & \text { 北見 } & \text { 啓之 } & \text { 佐藤 } & \text { 信紘 }\end{array}$

目的: 葉酸の関連化合物の一つである Neopterin ( Np n）は, 細胞性免疫能の活性化の指標として注目されて いる. 今回われわれは，C型慢性肝疾患患者末梢血単核 球の $\mathrm{Npn}$ 産生能抢よび患者尿中 $\mathrm{Npn}$ を測定し，イン ターフェロン（IFN）療法の治療効果との関連性につい て検討した。

方法 : IFN 療法を行った C 型慢性肝疾患患者 29 例を対 象として, 治療前の尿中 Npn および患者末梢血単核球 に IFN- $\gamma$ を添加した時の Npn 産生能を HPLC そよ り測定し, IFN の治療効果との関連性を検討した。

結果: 尿中 Npn は IFN 著効群および不応群で高值で あり, 治療後, 再発群・対照群では低值を示した. Npn 産生能は各群間で差は認めなかったが，Npn 産生能／ 尿中 $\mathrm{Npn}$ 比は, 著効群は 1 亿近い值を, 治療後再発群 は高值を，不応群は低值をとる傾向がみられ，C 型慢性 肝疾患の IF N 療法の治療効果には生体の細胞性免疫能 が関与しており，その予測および対策には尿中 Npn の 測定が有用である可能性が示唆された。

\section{In vitro 胃粘膜上皮細胞修復機構に関する EGF・ Insulin の効果}

消化器内科 前広 康平 渡辺 純夫
大藏 隆一 広瀬美代子
小林 修 永 原 章仁
村井 敏夫 遠藤啓一郎
三上 秀明 佐藤 信紘

目的: 初代培養胃粘膜細胞を用いた wound repair モ デルを作製し，損傷修復に対する EGF・insulin の影 響を検討した。

方法 : 初代培養胃粘膜細胞は家兔より摘出した胃から collagenase 消化法で作製後, F-12培養液にて培養し， 48時間後に confluent になるように調整した. confluent cell sheet 汇面積一定の円形 wound 老作製し, EG $\mathrm{F} \cdot$ insulin を添加後, 位相差顕微鏡下で経時的に wound の面積を計測し修復過程への影響を検討した。

結論：損傷作製直後約 $2 m^{2}$ であった wound は, 対 照群では48時間後に, EGF 群では 36 時間後に完全修復
した. insulin 添加群でも EGF 群と同様の傾向がみら れ, EGF + insulin 添加群では 24 時間後には完全に修 復された。乙れらの結果から, EGF・insulinは共に損 傷修復に対して促進的江㗢き, 特に, EGF とinsulin を同時添加するてとによって相加的な損傷修復能を示す ことが明らかとなった。

17. ラット胃粘膜における Gap 結合蛋白（connexin 32）発現の免疫組織学的検討

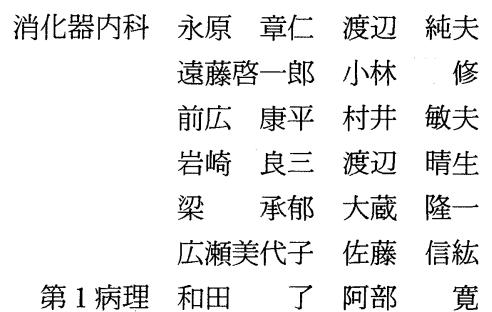

目的: Gap 結合は細胞間の情報伝達, 分化増殖に関与 しているとされる. 本実験はラット胃粘膜における Gap 結合蛋白の発現を免疫組織学的に検討し, 胃粘膜 細胞回転における Gap 結合の役割を明らかにした。

方法：Wistar 系雄性ラットを用い, bromodeoxyuridine $(B r d U)$ 投与 1 時間後に屠殺した. 胃粘膜の縦切 り切片を作製し, 胃底腺領域の H.E.染色および connexin 32蛍光染色を抢てなった. 抗 BrdU 染色により Br$\mathrm{dU}$ 陽性の細胞增殖帯を $\mathrm{PZ}$ とし, それより表層部を $\mathrm{SZ}$, 腺部を $\mathrm{GZ}$ とした. 各領域単位面積当たりの connexin 32陽性蛍光 spot を計測した。

結果 : $\mathrm{BrdU}$ 陽性細胞層は胃粘膜の上部 3 分の 1 亿観察 された. connexin 32は被蓋上皮表層に強い蛍光が観察 され，腺部では散在性に観察された。増殖帯ではほとん ど観察されなかった。陽性 spotは SZ では29.6

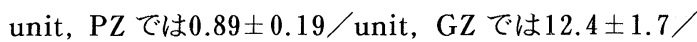
unit であった.

\section{8. 培養伊東細胞の增殖と運動に及ぼす bFGF の影響 \\ 消化器内科 汪 先恩 渡辺 純夫 広瀬美代子 横井 幸男 駒田 敏之 佐藤 信紘}

目的 : basic fibroblast growth factor (bFGF) は, 間葉系細胞の増殖因子として知られており, 腺維芽細胞 や内皮細胞の増殖, 血管新生促進作用を示す.今回は, 初代培養伊東細胞を用いて bF GF の増殖・細胞遊走に 与える影響を検討したので報告する。 
方法 : ラット肝より既報の方法で伊東細胞を分離・培養 した. bFGF ( $0.1 \quad 1 \quad 10 n g / m l)$ は, 培養液中に添 加し, 細胞増殖能は, BrdU の標識により検討し, 伊東 細胞の遊走能は time-lapse VTR で連続撮影の後, 1 時間あたりの遊走距離を画像解析し比較検討した。

結果 : BrdU の labelling index は対照群で $18 \%, b F$ GF $0.1 n g$ 群で33\%, $1 n g$ 群で42\%, 10ng 群で $58 \%$ で 有意に増加した。 細胞の遊走能は, 対照群で $6.4 \times 10^{-2}$ $\mu m / \mathrm{h}, \mathrm{bFGF}$ 群 $(10 \mathrm{ng} / \mathrm{ml})$ で11.4 $\times 10^{-2} \mu m /$ $\mathrm{h}$ であり有意㲹促進がみられた。

$\mathrm{bFGF}$ は伊東細胞の増殖・遊走を促進することより, 腺維化等に影響を与える可能性が示唆された。

\section{9. ラット消化管粘膜上皮における myosin-I の分布に $\supset$ ऽて

$\begin{array}{rlrl}\text { 消化器内科 山口 泰 広瀬美代子 } \\ \text { 北村 庸雄 竹内 真 } \\ \text { 宮崎 } \\ \text { 招久 } \\ \text { 渡边 } & \text { 純夫 } & \text { 佐藤 } & \text { 信男紘 }\end{array}$

目的 : 近年 myosin (myosin-II) 乙類似な性質を持つ, 単頭のタンパク質が発見され，乙れと類似の物質が鶏お よび牛の小腸上皮に存在するてとが報告されている．今 回われわれは下記のペプチドに対する抗体を作製し,ラッ 卜消化管粘膜上皮におけるその存在と分布を調べた。

方法: 合成ペプチド・ANMAYQSLRDRDRDQC を KL $\mathrm{H}$ 化し，アジュバントを用い克治免疫し抗体を得た。特 異性は鷄小腸刷子縁, およびラット小腸上皮細胞由来の 蛋白汶対し immunblot 法で行った。 また, 蛍光抗体法 でラット小腸・胃・大腸の myosin-I の存在と分布を 調べた。

結果 : blot では鵎刷子縁・ラット小腸上皮の $110 \mathrm{kD} の$ 蛋白と特異的㲹反応し, myosin-Iを認識するものと考 えられた. myosin-II等の他の蛋白とは反応しなかった。 免度染色では, ラット小腸上皮の緁毛内腔側，すなわち 刷子縁に一致して強く染色された．また細胞間にも弱く 反応した. 胃粘膜上でも胃腺内腔側が染色され, 大腸粘 膜上にても同様であった。
20. 培養胃粘膜細胞に対するアンモニアの影響

$\begin{aligned} & \text { 消化器内科 } \text { 村井 敏夫 渡辺 純夫 } \\ & \text { 小林 修 前広 康平 } \\ & \text { 永原 章仁 遠藤啓一郎 } \\ & \text { 広瀬美代子 三上 秀明 } \\ & \text { 大蔵 隆一 佐藤 信紘 }\end{aligned}$

目的: 近年, Helicobacter pylori の胃粘膜障害にアン モニアが重要な役割をはたすと考えられているが, 詳細 は不明である. 今回著者らは培養胃粘膜細胞汇対するア ンモニアの影響を形態学的に検討した。

方法 : 家兔より胃を摘出し, 胃粘膜を剝離細切し collagenase 法・低速遠沈法により調整し単離胃粘膜細胞と した。乙れを F-12培養液に $10 \%$ 胎児牛血清を添加して 48時間培養した. confulent になったのを確認後アンモ ニアを $3 \mathrm{mM} \quad 10 \mathrm{mM} \quad 30 \mathrm{mM}$ を加光 1 時間経過した のち, 顕微鏡下に細胞の変化を観察した。対照群として $\mathrm{KOH}$ にて pH を一致させた群を用いた。

結果 : 培養胃粘膜細胞にアンモニアを添加すると 3-30 $\mathrm{mM}$ では viability には変化なかったが, 濃度依存的に 壁細胞を中心とした細胞質内の空胞形成を惹起した。 こ の変化は, 対照として $\mathrm{KOH}$ を用いて $\mathrm{pH}$ を一致させた 群には観察されなかった. 電子顕微鏡による観察でもア ンモニア群のみに壁細胞を中心とした空胞形成が観察さ れた。

21. 肝細胞間コミュニケーションに対する細胞外基質の 影響

$\begin{array}{rrrr}\text { 消化器内科 } & \text { 池嶋 } & \text { 健一 } & \text { 渡辺 } \\ \text { 純夫 } \\ \text { 北村 } & \text { 庸雄 } & \text { 広瀬美代子 } \\ \text { 山口 } & \text { 泰 } & \text { 宮崎 } & \text { 招久 } \\ \text { 横井 } & \text { 幸男 } & \text { 北見 } & \text { 啓之 } \\ \text { 佐藤 } & \text { 信紘 } & & \end{array}$

目的 : ギャップ結合を介した細胞間コミュニケーション (IC) は, 細胞の分化・増殖や癌化仼関連があると考元 られている. 今回はICにおよぼす細胞外基質の影響を検 討した.

方法：コラーゲン $(\mathrm{COL}) \cdot$ フィブロネクチン $(\mathrm{FN})$ およびラミニン (LN) をコーティングした dish で, 肝細胞初代培養を行った。肝細胞 doublets 亿蛍光色素 をマイクロインジェクションして色素移行を観察し，ま たコネクシン 32 分布を比較検討した。

結果 : ICは培養時間経過と共に低下した. COL および F N 存在下では IC は早期より低下し，LM 存在下では 
保持された.コネクシン 32 の分布と量には有意な差を認 めなかった。

\section{Transforming growth factor の胃粘膜損傷修復} 能に与える影響

消化器内科 小林 修 渡辺 純夫 前広 康平 村井 敏夫 永原 章仁 大蔵 隆一 広瀬美代子 遠藤啓一郎 三上 秀明 佐藤 信紘

目的 : 胃粘膜損傷後, TGF $\alpha$ 分泌の増加を認め, 損傷 の修復促進淮く可能性が示唆されている．また，TG $\mathrm{F} \beta$ は上皮細胞に対しては増殖抑制性に㗢くことが報告 されている. 初代家免胃粘膜上皮培養細胞を用いた， wound repair モデルを作製し, TGF $\alpha$ TGF $\beta$ の影 響を検討した。

方法 : 培養胃粘膜細胞は，既報のでとく48時間後に完全 に confluent な状態になるように調整し培養した。人 工的胃粘膜損傷は, 面積の一定の wound を作製し，位 相差顕微鏡で損傷面積を経時的に測定し, 対照群と TG $\mathrm{F} \alpha$ 群・TGF $\beta$ 群につき比較検討した，細胞増殖は BrdU 染色を用いて検討した。

結果 : 人工的損傷は, wound 作製後, 損傷辺縁にある 細胞が，偽足様突起を形成し遊走，損傷が修復するまで 続いた. wound は対照群では損傷後 48 時間で修復した が, TGF $\alpha$ 群で著明に促進された。TGF $\beta$ 群では各濃 度で対照群との有意差は認められなかった。 細胞増殖は TGF $\alpha$ で促進され, TGF $\beta$ では変化はなかった。

\section{Kupffer 細胞の貪食能におよぼす pertussis toxin の影響}

消化器内科 広瀬美代子 渡辺 純夫 竹内 真 北村 庸雄 山口 泰 柚本 敦子 鈴木 聡子 池嶋 健一 横井 幸男 宮崎 招久 佐藤 信紘

目的: Kupffer 細胞の貪食機構への細胞内情報伝達夕 ンパクの関与を検討するため, G-protein の阻害剂を 用い, 貪食能および microfilamentsを中心とした細 胞骨格の局在変化を観察した.

方法 : ラット肝より collagenase灌流法, Percoll 比重 遠心法にて Kupffer 細胞を分離培養後 Pertussis toxin
添加による polystylene beads の取り込みの変化を位 相差顕微鏡にて計測した. また蛍光抗体法を用いて細胞 骨格を染色し, 共焦点レーザー顕微鏡にて観察を行った。 結果 : Kupffer 細胞の beads の貪食能はPertussis toxin により濃度依存性に低下した。ささらに正常 Kupffer 細胞で認められた貪食 bead 周囲の actin, myosin の集積は有意に減少した，以上の結果より G-protein を介する細胞内情報伝達機構は, Kupffer 細胞の貪食 に影響を及ぼす ruffling 運動の維持に必要な細胞膜下 の actomyosinの集積および制御に重要な役割を担っ ている可能性が示唆された。

\section{4. 細胞増殖と細胞内 $\mathrm{Ca}^{2+}$ oscillation 発現に関する} 解析

\begin{tabular}{|c|c|c|c|c|}
\hline 消化器内科 & 北村 & 庸雄 & 渡辺 & \\
\hline & 広瀬 & 言代子 & 宮崎 & \\
\hline & 竹内 & 真 & 山口 & \\
\hline & 柚本 & 敦子 & 鈴木 & \\
\hline & 池嶋 & 健一 & 北見 & \\
\hline & 佐藤 & 信紘 & & \\
\hline
\end{tabular}

目的: われわれは, phenylephrine 刺激後の[ $\left[\mathrm{Ca}^{2+}\right]$ i 動態を hepatocyte doublets を用いて観察し, 細胞 増殖状態と $\left[\mathrm{Ca}^{2+}\right] \mathrm{i}$ oscillation発現の関連性につい て比較検討した。

方法 : コラゲナ一ゼ灌流法により初代培養 hepatocyte doublets を ( I 群) 正常ラット, (II 群) 70\%肝切除18 時間後ラットより作成した. $\left[\mathrm{Ca}^{2+}\right] \mathrm{i}$ は, 細胞を $4 \mu$ M fura-2/AM 添加 PSS solution で30分間前処置後, 画像解析装置に接続した倒立顕微鏡を用い測定した。

結果 : phenylephrine 刺激により〔 $\left.\mathrm{Ca}^{2+}\right] \mathrm{i}$ oscilla-

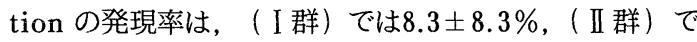
は68.2 $11.1 \%$ であった。また, oscillation が認めら れた doublets では, 隣接した細胞における各々の $\left[\mathrm{Ca}^{2+}\right] \mathrm{i}$ の変化は同期せず, 細胞間コミュニケーショ ン能の低下によるものと考えられた．以上の結果より $\left[\mathrm{Ca}^{2+}\right] \mathrm{i}$ oscillation の発現と細胞増殖機構の間には 密接な関係があることが示唆された。 
25. PBC の治療経過における anti-M2 の変動とその解 析

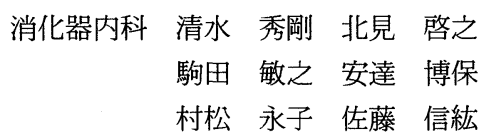

目的：今回われわれは, PBC 長期経過例における Ursodeoxycholic acid (UDCA) とPrednisolone (PSL) 投与による anti-M2 抗体の主要抗原との反応 の変化と AMA 抗体価の変動を検討し, さらに, UDC $\mathrm{A}$ 投与例の各抗原に対する anti-M2 の反応と検査成績 の推移を比較した.

対象・方法 : 6 〜8力月観察した UDCA 投与16例, PS L 投与 8 例が対象で自然経過観察 8 例を対照とした。投 与後 6〜12 力月毎の血清加ら Immunoblot 法により anti-M2 を測定し, AMA 抗体価の変動と比較し, また UDCA 長期投与例18例について anti-M2 の各主要抗 原への反応性と検査成績との比較を行った.

結果：UDCA 投与例では anti-M2 の反応抗原数に変 化はなく, PSL 投与例では反応抗原数や抗体濃度が減 少し, UDCA は anti-M2 産生細胞の抗原認識能には影 響しない一方で, PSL は抗原認識能や抗体産生能に影 響を及ぼし，また UDCA 投与例で24力月後より GPT・ ALP・T-Bil の再上昇が見られ，50kD 陽性例で特にそ の傾向が強く, UDCA 治療の限界が示唆された。

26. Enalapril とProbucol の糸球体硬化と活性酸素 におよぼす影響

$\begin{array}{llll}\text { 腎臓内科 } & \text { 唐 } & \text { 政 } & \text { 福井 光峰 } \\ & \text { 白土 公 海老原 功 } \\ & \text { 高野 一代 上田 りか } \\ & \text { 富野康日己 } \\ \text { 小吉川 睦子 } \\ \text { 小出 輝 }\end{array}$

目的 : $5 / 6$ 腎摘ラットを作成し, 糸球体硬化の進展に おける抗酸化酵素の役割について検討した。ささらに, 抗 酸化剂 (Probucol（P) 1 \% 含有飼料) あるいは降圧 剂 (Enalapril (E) $100 \mathrm{mg} / \mathrm{L}$ 飲水) 投与の影響につ いても検討を加えた。

方法 : 5 週齢SD ラットに $5 / 6$ 腎摘を行い, 術後 4,8 , 12週後の糸球体 MDA 量, SOD および GSH-Rx 活性 を測定した. さらに, 術後 2 週から P または $\mathrm{E}$ の投与 を開始し, 術後12週にて同様の検討を行った。

結果 : $5 / 6$ 腎摘群では, 対照群と比較し糸球体 MDA 量は増加, SOD および GSH-Px 活性は低下を示した。
一方, $\mathrm{P}$ または $\mathrm{E}$ の投与により, それらの変化は是正さ れた。

結論 : 以上の結果より, 糸球体硬化の進展に活性酸素系 の生成・消去の不均衡関与しているてとが示された。 また, $\mathrm{P}$ あるいは $\mathrm{E}$ の投与は, 乙の不均衡を是正し, 系 球体硬化を抑制しうる可能性が考えられた。

27. 糸球体硬化症（FGS）モデルにおける糸球体 MM Ps および TIMP-1 mRNA レベルにおよぼす低蛋 白食投与の影響

\begin{tabular}{|c|c|c|c|}
\hline 腎臓内科 & 福井 & 光峰 & 中村 \\
\hline & 白土 & 公 & 海老原 \\
\hline & 高野 & 一代 & 上田 \\
\hline & 吉川 & 睦子 & 富野康日 \\
\hline & 小出 & 輝 & \\
\hline
\end{tabular}

目的：FGSの発症機序を明らかにする目的で, FGS モ デルでの糸球体 MMPs および TIMP-1 mRNA レベ ルの変化を検討, さらに低蛋白食投与の效果についても 検討を行った。

方法 : 既報のごとく PAN +片腎摘にて FGS モデルを 作成し, 通常蛋白食 $(22 \%)$ 挨よび低蛋白食（6\%) 投 与群に分け，PAN 投与48，60，80日目に Northern blot 法にて, 糸球体 MMPs および TIMP-1 mRNA レベルの変化を検討した.

結果 : 糸球体 MMP-1, -3 レベルには変化は認めなかっ たが, 糸球体 MMP-2 および TIMP-1 mRNA レベル は, 糸球体硬化の進展とともに増加を示した. 低蛋白食 にててれら変化は是正された。

結論 : 糸球体硬化の進展には糸球体細胞外基質の産生増 加（一昨年報告）と分解抑制力関与し, 低蛋白食系球体 硬化抑制作用は昨年報告のでとくサイトカインの抑制を 介するものと考えられた。

28. ループス腎炎モデル NZB／WF 1 マウス腎におけ る MMP, TIMP 発現一ステロイドの影響

$\begin{array}{rlrl}\text { 腎藏内科 } & \text { 中村 司 海老原 功 } \\ & \text { 福井 光峰 } & \text { 長田しをり } \\ & \text { 高野 一代 上田 りか } \\ & \text { 富野康日己 小出 輝 } \\ \text { 共同生化 } & \text { 吉川 睦子 } & & \end{array}$

目的 : 著者らは NZB /WF1 マウス腎において腎炎の進 行とともに, ECM 成分・ET・各種増殖因子の発現が 増加するてとを報告している．今回， ECM を調整する 
因子としての MMP・TIMP 発現, およびステロイド投 与によるてれら因子への影響について検討した。

方法 : 8, 24，48週齢の NZB /WF 1 マウス腎より RNA を抽出し, Northern blot を施行した. 20週齢よりパル ス療法に準ずるステロイドを投与した。 MMP-1 $\begin{array}{lll}-2 & -3 & -9 \\ -1\end{array}$

結果 : 週齢ととも江糸球体細胞数増加, 基質の拡大, 間 質の著明な細胞浸潤・蛋白尿がみられた. MMP・TIMP のmRNA レベルも週齢とともに増加し, TIMP の増加 が各 MMP の増加に比し顕著であった。ステロイド投 与により組織の著明な改善, および MMP・TIMP の発 現も抑制された。

結論：NZB／WF1 マウスの糸球体腎炎・糸球体硬化進 展に MMP・TIMP の関与が示唆された。

\section{IgA 腎症モデル ddYマウス腎におけるエンドセリ} ン発現

腎臟内科 中村 司 福井 光峰
海老原 功 高野一代
上田 りか 富野康日己
小出 輝

共同生化 吉川 睦子

目的 : 腎炎発症・進展に ET の関与が推測されている. $\mathrm{IgA}$ 腎症モデルマウスにおける $\mathrm{ET} ・ \mathrm{E} \mathrm{T}_{\mathrm{R}}$ の発現，およ び調整因子である TGF- $\beta$ ・TNF- $\alpha$ の発現を検討した. 方法 : 8, 32, 60週齢の ddY マウス腎を摘出し RNA t 抽出, Northern blot 施行した. ET-1 -3・ET receptor-A $-\mathrm{B} \cdot \mathrm{TGF}-\beta \cdot \mathrm{TNF}-\alpha$ の mRNA レべ ルを測定した.

結果 : 週龃とともにddY マウス腎では, 糸球体細胞数 の増加，基質の拡大および蛋白尿増加がみられた。腎炎 の進行とともにET-1・ET receptor-A -B の mRNA レベルも増加し，60週齢ではコントロールに比し， 5，3， 2 倍増加したが，ET-3 は変化を示さなかった。 TGF$\beta \cdot \mathrm{TNF}-\alpha \mathrm{mRNA} も 60$ 週齢ではコントロールに比 し 5,3 倍に増加した。

結論 : ET-1・ETr は腎炎の進行ととも増加し, TGF$\beta \cdot \mathrm{TNF}-\alpha$ も平行して増加するととより, $\mathrm{dd} \mathrm{Y}$ マウス の腎炎進展に上記の因子が関与することが示唆された。
30. 糖尿病モデル腎における MMP・TIMP の発現一イ ンシュリンおよびエナラプリルの影響

腎臓内科 中村 司 福井 光峰
海老原 功 長田しをり
山本 雅俊 高橋 俊雅
蒔田雄一郎 高野 一代
上田 加 富野康日己
小出 輝

共同生化 吉川 睦子

目的 : 著者らは, DM 腎症モデルでの ECM, 増殖因子 発現異常を報告している. 今回, MMP・TIMP の発現 およびインシュリン・エナラプリルの影響について検討 した。

方法 : SD ラットに STZ を投与し DM を作成し， 4, 12, 24週後汇系球体から RNA を抽出し, Northern blot を施行した。治療としてインシュリンを 4 週目まで，工 ナラプリルを 24 週まで投与した. MMP-1 TIMP-1の mRNA レベルを各群てついて検討した。

結果 : MMP-1 -3 は週齢とともに減少し, MMP-2 は 変化を示さなかった. MMP-9 は発現を認めず, TIMP は増加した。インシュリン投与により血糖を調整するこ とにより上記の mRNA レベルは是正された。 エナラプ リルは蛋白尿を減少させたが, 上記の mRNAレベルに は全く影響しなかった。

結論：DM 腎症では MMP・TIMP の異常な発現が糸 球体硬化関与し, 血糖が重要な役割を果たしているて とが示唆された。

\section{1. 胎児肺低形成の病態生理に関する実験的検討 \\ 小児外科 細田弥太郎 岡田 安弘 宮野武}

目的 : 胎览肺低形成の病態を解明するため, 仮説 (胎児 肺の発育は, 腎臓で生産される pulmonary growth factors $<\mathrm{PGF}>$ により促進され, そのフィードバック シグナルとして, 肺から pulmonary derived renotro$\operatorname{pin}<\mathrm{PDR}>$ が産出される) を立て, 先天性横隔膜ヘル 二アと羊水過少症実験モデルで一部を証明した. 更にて の仮説を立証していくために，実験を行った。

方法: 妊娠家鬼を用い, 胎仔左肺切除術を施行した。 出 生時に肺と腎重量を測定し, 各臓器の DNA・総蛋白分 析を施行した. コントロールとして, 同母体内非手術胎 仔を用いた。

結果 : 実験モデルの肺・腎は, コントロールに比して, 
低形成を示した。

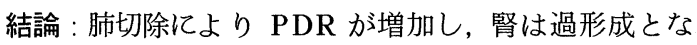
ると予想したが, 相反する結果となった。 ての病態とし て, PDR がPGFより優位に㗢くことが推測され, PDR の減少か腎低形成に結び付いていると考えられた。

\section{2. 子宮頚部病変における PCNA 発現の免疫組織学的 検討}

$\begin{aligned} & \text { 産婦人科 古堅 善亮 鈴木 正明 } \\ & \text { 臼井 直行 宮沢 真紀 } \\ & \text { 桑原 慶紀 } \\ &\end{aligned}$

目的: Proriferating cell nuclear antigen (PCNA) の子宮頝部病変における発現を免疫組織学的に検討した。 方法: 対象は当科外来で経過観察をしている軽度異形成 6 例・中等度異形成16例・高度異形成18例である. コル ポスコピー下に病変部分の生検を施行し, 一部は組織学 的検索を行い, 一部は今回の研究の材料として用いた。 $10 \%$ ホルマリン固定後パラフィン包埋切片に対して, 抗 $\mathrm{PCNA}$ モノクローナル抗体を使用し $\mathrm{ABC}$ 法による染 色を行った。陽性率は病変部分の細胞 600 個のうち陽性 細胞を算定し, 100分率にて表した。

結果 : PCNA 陽性率は軽度異形成で $19.4 \%$, 中等度異 形成で $29.3 \%$, 高度異形成で $35.3 \%$, 病変が進行する につれて陽性率は上昇した。 また経過観察例では形態学 的に変化する前から, PCNA 陽性率は進行例では上昇, 退行例では低下していた。

33. 肝炎患者のクリオグロブリンおよびクラス別リウマ トイド因子の測定

膠原病内科 笑 剛小林茂人 田中 光彦 橋本 博史 廣瀬 俊一

共同生化 田嶋美智子

目的 : 肝炎患者血清中にリウマトイド因子（RF）を認 め, 特に C 型肝炎はクリオグロブリン (CG) が認めら れる。

方法 : HBs Ag ・ HCV Ab 陽性者血清を $4{ }^{\circ} \mathrm{C} に て 1$ 週間 整置し, 沈殿を洗浄して $37^{\circ} \mathrm{C} て ゙$ 溶解し, 再び $4{ }^{\circ} \mathrm{C} 1$ 週間 整置し，沈殿が存在したものを CG 陽性とした。また， 処理前の血清のクラス別（RF）をELISA にて測定し た。

結果: HCV 抗体陽性血清 $(\mathrm{HCV} \mathrm{Ab+)} 178$ 検体のう ち, CG は29検体 (16.3\%) 亿陽性であった. HBsAg
陽性血清（HBsAg +) 39 検体では 1 検体のみ力陽性でか り, 有意差を認めた $(\mathrm{P}<0.05)$. クラス別 RF は $\mathrm{HCV}$ $\mathrm{Ab}+30$ 検体, HBsAg +12 検体を測定した結果, IgGRF 陽性は $\mathrm{HCV} \mathrm{Ab+5}$ 例 $\cdot \mathrm{HBsAg}+0$ 例, IgMRF が $\mathrm{HCV} \mathrm{Ab}+4$ 例 $\cdot \mathrm{HBsAg}+3$ 例, IgARF が $\mathrm{HCV}$ $\mathrm{Ab}+4$ 例・HBsAg +3 例に陽性であり, その抗体価は IgGRF 亿おいて HCV AB 陽性検体にて有意洫かった $(\mathrm{p}=0.03)$.

考案 : 肝炎の差異によって RF の産生が異なり, HCV 肝 炎では IgGRF・CG のため, 血清障害が起こるととが示 唆された。

\section{4. 抗カルジオリピン抗体（ACA）のIgGーリウマトイド 因子活性 (IgGRF) について \\ 膠原病内科 小林 茂人 塩見 治子 田中 光彦 山路 健 金井 美紀 津田 裕士 橋本 博史 廣瀬 俊一 共同生化 奥田 則子}

目的: 自己抗体の poly reactivity が知られている. ACA (IgG) のIgG-RF 活性を検索した.

方法 : 1) 東大薬学部・順大第 2 病理汃ら供与されたモノク ローナル ACA ( $\operatorname{IgG})$ の RF 活性を検討. 2) SLE, RA 患者, 18 血清のIgG をFcまたはBSA-Sepharoseにて吸収し, ACA, IgG-RF を測定. 3) IgG-RF 陽性 7 患者を dextran sulfate column による血漿交換 吸着法を施行, 前後の RF を測定した。

結果 : 1) PS 免度マウス, NZB $/ \mathrm{W}$ F1 から得られた AC A にIgG-RF を認めた。 2) 患者IgG はFc-Sepharose によって ACA 活性の有意の低下を認めた. Fc Sepharose 亿吸着した IgG 4 検体に高い ACA 活性を認 めた. 3) dextran sulfate column による血獎交換では IgG-RF のみか IgM-RF・Ig A-RF と比べ有意の低下を 示した.

考案: natural occurring polyreactive autoantibody は移植の hyper acute rejection に関与する. 自己抗体の なかで polyreactive autoantibody は pathogenic の 抗体であるととが示唆された。 
35.レチノン酸による血管内皮細胞上の Thrombomodulin $の$ up-regulation について

膠原病内科 塩見 治子 小林 茂人 田中 光彦 橋本 博史 廣瀬 俊一

共同生化 大柳むつ子

目的：トロンボモジュリン（TM）は血管内皮細胞上に 存在し, トロンビンやプロテイン C の受容体であり, 血 管内凝固を抑制する. IL-1 や LPS では TM のdownregulation が起乙り, グルココルチコイドでは upregulation が起乙る. 今回, レチノン酸（all trans retinoic acid：ATRA）によるup-regulatuion を検 討した.

方法: HUVEC $1.52 \times 10^{4} /$ well te triplicate にて 4 日間培養し, ATRA $1.0 \times 10^{-5} \mathrm{M}(3.004 \mathrm{mg} / \mathrm{L})$ 亿交 換し24時間培養した. この後, Mo-anti-TM 抗体によ る cell ELISA を行った。

結果 : 対照の optical density (OD) の平均値および SD $0.259 \pm 0.030$ であったが, ATRA 添加の OD の

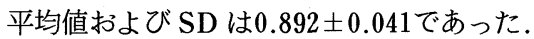

考案 : In vitro に扔けるレチノン酸による TM のup-re gulation の結果汃ら, レチノン酸投与により血栓症・ 動脈硬化などの予防効果が推定された。

36. NZB／F1 マウスから得られたモノクローナル抗ト ロンボモジュリン抗体の B2-glycoprotein I に対 する反応性の検討

膠原病内科 掘合 愛子

(東邦大学理学部生物分子科学科)

小林 茂人 別府 幸江

春田 和彦

(全薬工業研究所)

橋本 博史 廣瀬 俊一

共同生化 大柳むつ子

病理学第二 斉川 雄弘 廣瀬 幸子

目的: 抗カルジオリピン抗体 (ACA) の対応抗原はカ ルジオリピン (CL) とB2-glycoprotein I (B2GPI) の複合体と考元られているが，特殊な方法では ACA は B2GPI 亿のみ反応すると言われている. NZB／F1 マ ウスから得られた抗トロンボモジュリン抗体を使用して CL・B2GPI 亿対する反応を検索した。

方法：B2GPI を抗原とした通常のELISA を行った. B2GPIによる吸収試験を行った。抗体のトロンボモジュ
リン（TM）の CL・B2GPIに対する affinity を求め た。

結果：通常の ELISAにて CL・B2GPI 亿反応するモノ クローナル抗トロンボモジュリン抗体が存在した．反応 はB2GPIによって吸収された。affinity はTMが1.7$5.2 \times 10^{8}, \mathrm{CL}$ が $2.1-8.0 \times 10^{-5}, \mathrm{~B} 2 \mathrm{GPI}$ が $1.1-3.7 \times$ $10^{6}$ であった。

考案 : NZB / F1 マウスからトロンボモジュリンに反応 するモノクローナル抗体が得られ，乙の抗体は通常の $\mathrm{E}$ LISA にて CL・B2GPI・IgGFc などに polyreactivity を示した。 affinity がB2GPI >CL より, pathogenic な抗体と考光る。

37. LDL 亜分画と冠動脈疾患および各動脈硬化危険因 子との関連について

\begin{tabular}{|c|c|c|c|}
\hline 循環器内科 & 参木 & 保至 & 本野 \\
\hline & 藤岡 & 治人 & 藤原 \\
\hline & 渡辺 & 嘉郎 & 佐藤 \\
\hline & 山口 & 洋 & \\
\hline 生化学第二 & 岩㴊 & 和久 & 長岡 \\
\hline & 山下 & 辰久 & \\
\hline
\end{tabular}

目的: 小粒子 LDL と冠動脈疾患および他の動脈硬化危 険因子との関連を検討した。

方法 : 冠動脈撮影を施行した217例（男170 女47）の空 腹時血漿を用い, $2.5 \sim 16 \%$ 密度勾配ゲル電気泳動法に てLDL を正常群（N群）と小粒子群（S 群）に分類し た. 冠状動脈硬化病変は造影にて $75 \%$ 以上を有意病変と した.

結果 : S 群は冠動脈病変のない群（CAD - 群）で19.7 \%, ある群 (CAD+群) で46.8\%と CAD + 群に有意に 高かった. CAD+群では $\mathrm{S}$ 群は N 群纪比し高中性脂肪 (TG) 血症・低 HDL コレステロール $(\mathrm{HDL}-\mathrm{C})$ 血 症・高血圧症の合併が多かった. 病変指数の増加に伴い $\mathrm{S}$ 群の割合が増加する傾向にあった。

総括 : 小粒子 LDL は冠動脈硬化病変との関連が強く, 高 TG 血症・低 $\mathrm{HDL}-\mathrm{C}$ 血症・高血圧症等の危険因子 を高率に合併し，今後てうした各危険因子を総合的に改 善する必要があると思われる. 
38. 血中 Lipoprotein（a）（Lp（a））分画の精製と血 管内皮細胞への生理的影響

循環器内科 藤岡 治人 本野 浩司 渡辺 嘉朗 参木 保至 山口 洋

膠原病内科 金井 美紀 津田 裕士 臨床病理学 三宅 紀子

目的 : 動脈硬化症の危険因子である Lp（a ）の血管内 皮細胞への生理的影響を検討する. 今回は Lp（a）の 精製法の確立と精製した $\mathrm{Lp}$ （a）を用いての血管内皮 細胞への障害性およびその刺激に対する反応を培養細胞 を用いて検討した。

方法：高脂血症患者のLDL apheresisに使用した吸
着型血漿交換器から脂質成分を溶出し，乙れを超遠心分 離法で Lp (a) 粗分画を分離. Lysine-Sepharose gel による affinity chromatography で Lp（a）を精製 した。乙れを培養液中に加えて細胞を刺激し, 細胞障害 性や培養上清中の生理活性物質を測定することでin vitroの作用を検討した。

結果 : LP (a) は約 $60 m g / d l$ の濃度 (ELISA 法) で 分離されSDS-PAGE の免疫科学的方法で確認された. また，培養液中に Lp（a）を添加し48時間培養した場 合, 濃度依存性に内皮細胞障害を示した。血管内皮細胞 は多様な生理活性物質を産生し恒常性を維持しているが, 特に凝固系や増殖因子への関与が注目され, 今後の課題 である。

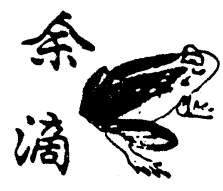

中野孝次氏の著書「清貧の思想」が出版されたのは 1992年の秋であるが，バブル崩壊の時流に乗って？ たちまちべストセラーとなり, 半年ほどして, その書 名にひかれ, 小生も講読した. 一年余の今もロングセ ラ一を続けており, 一寸した「清貧」ブームを巻き起 こしているという. 文章は平易で, 本書の内容と著書 の意とするとてろは明快である. それは, 日本の古典一 西行, 兼好, 芭蕉, 良寛など一を引きながら, 日本に は金儲けとか現世の栄達を求めず，ひたすら心の世界 を重んじる分化の伝統があった乙とを内外に紹介し， 物質万能的な風潮を批判している.

てれに対して各界で「清貧」論争なるものが行われ ているが，ひとつの社会現象として面白い． 曰く， “一億総清貧”になってしまうようでは困る，曰く， 個人がきちんと身を処していれば良い社会ができる， という考えでは社会は良くならない，日く，成長否定 の世捨て人だ。曰く，「清貧」よりも，ほどほどの
豊さのある「清潤」を提唱したい. 曰く, 清貧は近代 資本主義の根底にある質素と勤勉に, さらに細川首相 の「実質」にも通じる, 等々. いわゆる諸者の方々の 我田引水的議論に対して, 中野氏は「ての本は一文士 の夢を語ったものであり, 日本経済のあり方などを積 極的に提言する意図はない」と明言している。一方, 海外でもマスコうがこの本を大きく取り上げ，翻訳出 版の動きも相次いでいるという。

西行, 兼行, 芭蕉, 良寛はいずれも僧形ないしそれ に準ずる人士であり，中野氏が特に私淑しておられる のはその中で最も僧形に徹した人一良寛であるとお見 受けした，かく申す小生も良寛和尚を私淑敬慕する大 衆のひとりであり, 中野氏の筆致が文士の美意識に依 拠しているてとに喝采を送りつつも, その反面, 突っ 込みの物足りなさを覚えざるをえなかった。 中野氏は さらに続編を出版され，小生はそれを店頭で目にした が, 今のとてろ続編に対しては「清貧」を通している. (神経学 今井 壽正) 